\title{
Microstructure and fabric transitions in calcite tectonites from the Sierra Alhamilla (Spain).
}

\author{
By Jan H. BehrmanN, Oxford *) \\ With 7 figures and 1 table
}

\section{Zusammenfassung}

Eine Anzahl von Marmoren aus der Sierra Alhamilla (Spanien), intensiv deformiert unter natürlichen Bedingungen bei ca. $300^{\circ} \mathrm{C}$, zeigt ausgeprägte Variationen in Mikrostruktur und Gefüge. Es kann gezeigt werden, daß die Entwicklung von bevorzugten Kristallorientierungen und Formanisotropien im Korngefüge erheblich von der rekristallisierten Korngröße abhängt. Dies wird als Ausdruck der relativen Aktivität verschiedener Deformationsmechanismen interpretiert. Superplastizität scheint eine relativ scharf definierte Obergrenze für Korngrößen von $10-15 \mu \mathrm{m}$ zu besitzen. Im Bereich des Potenzgesetz-Fließens wird die Verformung feinkörniger Aggregate wahrscheinlich von Diffusion, die von grobkörnigen von Dislokationsmechanismen bestimmt. Der Übergangsbereich zwischen beiden Mechanismen umfaßt einen Korngrößenunterschied von etwa $30 \mu \mathrm{m}$.

\begin{abstract}
A suite of marble specimens from the Sierra Alhamilla (Spain), deformed to large strains under natural conditions at about $300^{\circ} \mathrm{C}$ shows distinct variations in microstructure and fabrics. It can be demonstrated that the development of crystallographic preferred orientations and grain shape fabrics are strongly dependent on recrystallized grain size. This is interpreted to reflect the relative importance of various deformational mechanisms. Superplasticity seems to have a sharp upper grain size limit at $10-15 \mu \mathrm{m}$. Within the power law creep regime, deformation in fine grained aggregates is probably dominated by diffusional, in coarser ones by dislocation mechanisms. The transition is a gradual one, and may span a grain size range of $30 \mu \mathrm{m}$.
\end{abstract}

\section{Résumé}

Une série d'échantillons de marbres de la Sierra Alhamilla (Espagne), fortement déformés sous des conditions naturelles de $300^{\circ} \mathrm{C}$, montre des variations distinctes de microstructure et de texture. On peut démontrer que la formation des orientations préférentielles cristallographiques et de l'aplatissement des grains dépend clairement des dimensions des grains recristallisés. Ceci est interpreté a comme le reflet de l'importance relative de plusieurs mécanismes de déformation. Il apparaît, que le domaine de superplasticité a une limite bien definie a $10-15 \mu \mathrm{m}$. Dans le domaine du fluage en $\sigma^{\mathrm{n}}$, la déformation des aggrégats fins semble être dominée par des mécanismes de diffusion, et des aggregats de grande taille par des mećanismes de dislocation. La transition est graduelle, et peut comprendre un intervalle dimensionel des grains de $30 \mu \mathrm{m}$.

\section{Краткое содержание}

Были исследовань мраморы из района Сиерра Алгамилла (Испания). На основании изучения их микроструктуры и строения считают, что их деформация происходила при примерно $300^{\circ} \mathrm{C}$. Установили, что образование и

*) Address of the author: J. H. Benrmann, Dept. of Geology and Mineralogy, University of Oxford, Parks Rd., Oxford OX1 3PR, England. 


\section{J. H. BehrmanN}

орнентация их кристаллов, а также анизотропия форм в структуре зерен зависят в большей мере от гранулометрического состава перекристаллизованного минерала. Это явление объясняют тем, что здесь действовали различные механизмь деформацни. Пластнчность их, кажется, ограничена гранулометри-ческим составом и лежит в размерности зерен между 10 и 15 микрон (верхняя граница). В области действительности закона ползучести материала преобразование мелкозернистьх аггрегатов предопределяется, вероятно, процессами диффузии, а грубозернистых-механизмами дислокации. Переходная зона между обонми механизмами, вероятно, лежит в размерности 30 микрон.

\section{Introduction}

Microstructure and crystallographic preferred orientations of polycrystalline calcite experimentally deformed in the ductile regime have received a lot of attention in recent years (e. g. KERN, 1971; WENK et al., 1973; Schmid et al., 1977, 1979). It was found that microstructure, especially the grain size of a deforming aggregate, critically influences the choice of creep mechanism, along with other variables such as temperature and differential stress. Experiments (e. g. HandiN and Griggs, 1951) and theory (LISTER, 1978) predict the development of crystallographic preferred orientations (fabrics), if the dominant mode of deformation is intracrystalline plasticity, i. e. dislocation glide or mechanical twinning. Furthermore, calcite fabrics may contain unique information about the kinematics of deformation (RutTer and Rusbridge, 1977).

This paper reports fabric and microstructural data from a suite of marble specimens, which have suffered large strain natural deformation under lowermost greenschist facies conditions. The aim is to elucidate the microstructural control on

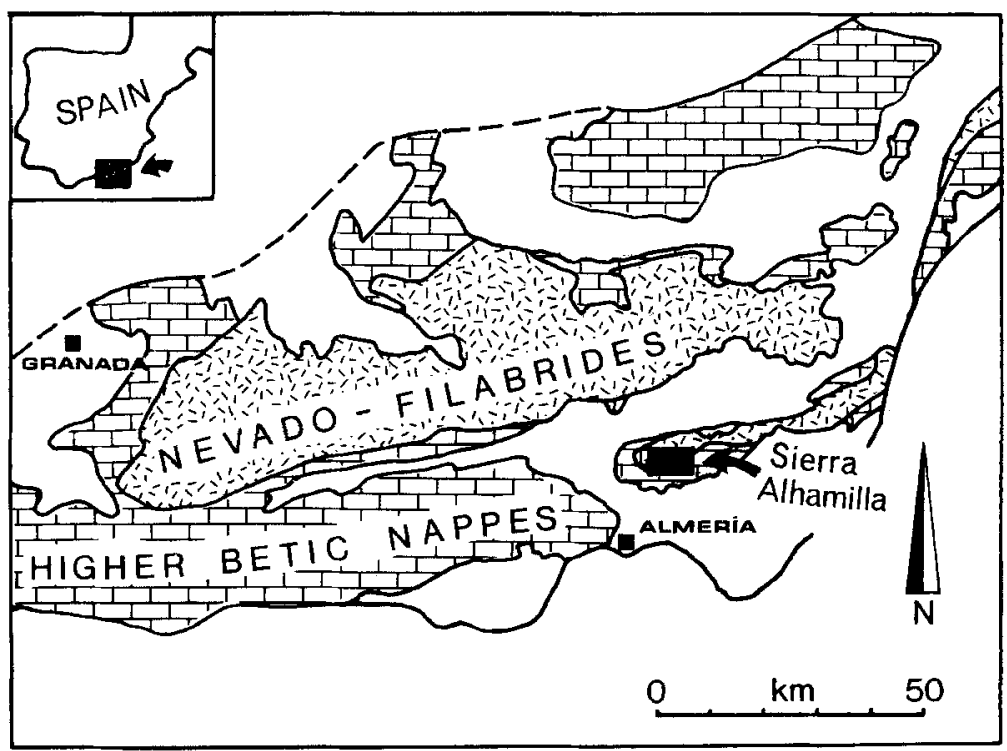

Fig. 1. Tectonic sketch map of the eastern Betic zone (after Platt, 1982). The position of the sampling area in the Sierra Alhamilla is indicated by the black rectangle. 


\section{Microstructure and fabric transitions in calcite tectonites}

fabric development, and to discuss its implications for the deformation mechanics of calcite tectonites in low grade metamorphism.

The six samples were collected from the eastern Betic Zone, the internal, mainly metamorphic part of the alpine Betic Orogen in southern Spain. For a review of regional geology and orogenic history, see EgeLER and Simon (1969), or TorkesRoldan (1979). The contact between the Nevado-Filabrides and the Higher Betic nappes is of fundamental tectonic importance, and may represent a fossil plate boundary, or suture zone (PLATT, 1982).

In the Sierra Alhamilla (Fig. 1), flow in a zone of strong contact deformation at the base of the Higher Betic nappes is linked to their emplacement over the NevadoFilabride complex (PlatT, 1982). All specimens come from this zone, except Pt 281, which is associated with a ductile fault within the Higher Betic rocks. For specification and location of the samples, see Table 1. Structural evidence (PLATt, 1982), and the sense of asymmetry of quarz c-axis fabrics (BEHRMANN and PLATT, 1982 ) indicate a north-northeast directed emplacement of the Higher Betic nappes, thus constraining a similar sense of vorticity (MEANs et al., 1980) in the large scale flow field. Ambient temperatures during flow were in the order of $300^{\circ} \mathrm{C}$, according to calcite-dolomite geothermometry (BICKLE and Powell, 1977) done on deformed, recrystallized specimens of marble from the area.

\section{Microstructure}

All specimens have a well developed mesoscopic foliation (Fig. 2). It is defined by shape preferred orientation of calcite grains in the rock matrix, and by compositional variations on a $\mathrm{mm}$ - to $\mathrm{cm}$-scale. A weak lineation due to the stretching of

Table 1: Localities of the analyzed specimens

\begin{tabular}{llll}
\hline $\begin{array}{l}\text { Specimen } \\
\text { No. }\end{array}$ & $\begin{array}{l}\text { Coordinates } \\
\text { (UTM, 30S/WF) }\end{array}$ & Locality & Lithology \\
\hline B9 & $555700 / 4091300$ & $\begin{array}{l}\text { Lower contact } \\
\text { of Castro } \\
\text { thrust slice }\end{array}$ & calcite-mylonite \\
B12 & $555700 / 4091300$ & $\begin{array}{l}\text { Lower contact } \\
\text { of Castro } \\
\text { thrust slice }\end{array}$ & calcite-mylonite \\
B43 & $558200 / 4091300$ & $\begin{array}{l}\text { Inverted limb } \\
\text { of Aguilon } \\
\text { fold nappe }\end{array}$ & $\begin{array}{l}\text { calcite-dolomite } \\
\text { mylonite }\end{array}$ \\
B96 & $557400 / 4092700$ & $\begin{array}{l}\text { Castro thrust } \\
\text { slice }\end{array}$ & $\begin{array}{l}\text { fine grained } \\
\text { marble } \\
\text { Pt205 }\end{array}$ \\
fine grained \\
st281
\end{tabular}


calcite matrix grains is developed on the foliations in specimens B 9, B 12, Pt 205, and $\mathrm{Pt} 281$. Rods of porphyroclastic grains of quartz, dolomite, or plagioclase define an extension lineation in B 9, B 12, B 43, B 96, and Pt 205. Tight to isoclinal folds of the compositional banding are developed on a cm- to $\mathrm{m}$-scale. Their axes are sub-parallel to the stretching lineation. They were probably rotated into this position after having originated at angles to it (ESCHER and WATTERSON, 1974). The axial planes of these folds are parallel to the foliation defined by the flattened calcite matrix grains. A frame of reference can then be set up, defined by the mesoscopic foliation as the XY-plane of finite strain (WiLliams, 1976), and the stretching lineation, which indicates the direction of maximum finite extension (Fig. 2).

Ultra-thin petrographic sections $(3-5 \mu \mathrm{m})$ were cut perpendicular to the mesoscopic foliation, and parallel and at a right angle to the stretching lineation, respectively. The preparation technique is described by VERNON (1981). The extreme thinning removes birefringence effects, thus allowing better study of grain boundaries and very fine grained aggregates.

B 96 and Pt 205 are fine grained marbles. The matrix grains are elongated in the $\mathrm{XZ}$-section, with an average axial ratio of $1.66: 1$ and $1.72: 1$. The aspect ratio in the YZ-section is about $1.3: 1$. The mean matrix grain sizes are $59 \mu \mathrm{m}$ and $45 \mu \mathrm{m}$. There is little e-twinning- but some undulatory extinction and subgrain formation (Fig. 3 a). Grain boundaries are curved or embayed. 30 to $40 \%$ of the rock volume is taken up by large $(0.3-1 \mathrm{~mm})$ grains of calcite. They show numerous e-twins, sometimes bent, and undulatory extinction (Fig. $3 \mathrm{a}, \mathrm{b}$ ). Recrystallisation occurs preferably along twin lamellae, and at grain peripheries. The fine matrix may then be a product of extensive, probably syntectonic recrystallisation of an originally coarse grained marble.

Specimens B 9 and B 12 (Fig. 3 c) are significantly finer grained calcite mylonites with some $(10 \%)$ porphyroclastic quartz and plagioclase. The average matrix grain sizes for calcite are 19 and $26 \mu \mathrm{m}$; XZ-aspect ratios are 1.54:1 and $1.65: 1$. Undulatory extinction is weak. About $10 \%$ of the calcite grains are larger (up to $0.5 \mathrm{~mm}$ ). They are elongated parallel to the foliation, occasionally e-twinned, and

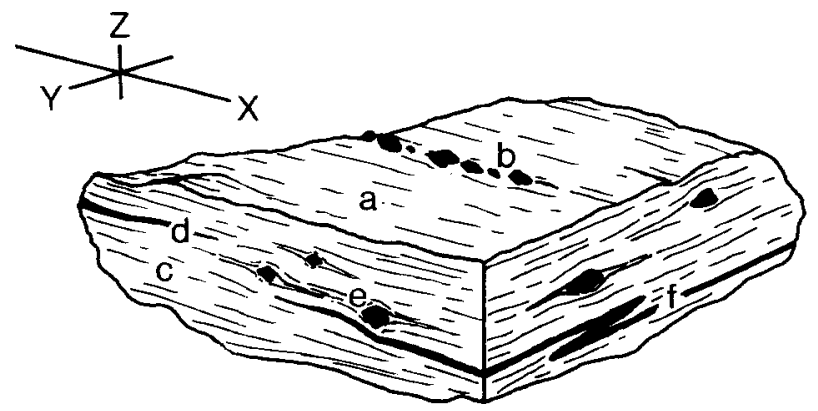

Fig. 2. Mesoscopic specimen attitude. Stretching lineation on the foliation (a); lineation made up by rods of porphyroclasts (b); foliation defined by flattening of grain aggregates (c), or by compositional banding (d). Porphyroclasts of dolomite, quartz, or plagioclase enveloped by the foliation (e); folds of the compositional banding (f). X, Y, Z are the inferred principal axes of finite strain. 


\section{Microstructure and fabric transitions in calcite tectonites}

sometimes show a well-developed subgrain structure. Grain boundaries are straight or slightly curved.

Pt 281 is a very fine grained calcite mylonite. The average matrix grain size is $15 \mu \mathrm{m}$; the XZ-aspect ratio is $1.44: 1$. Isolated calcite porphyroclasts are up to $100 \mu \mathrm{m}$ in size, and show marginal recrystallization to matrix grains. Undulatory extinction is weak, and there are no e-twins. Grain boundaries are straight or slightly curved.

B 43 has a matrix of very fine $(10 \mu \mathrm{m})$, equiaxial grains of calcite $(60 \%)$ and dolomite $(40 \%)$ (Fig. $3 \mathrm{~d}$ ). Most grain boundaries are straight. There is neither twinning nor undulatory extinction. Equant, up to mm-sized porphyroclasts of mostly untwinned dolomite, plagioclase, or white mica are dispersed in the matrix.

Relating to the variation in recrystallized grain size, the specimens show some remarkable differences in microstructure. Undulatory extinction seems to be strongest in the coarse varieties, indicating an increasing density of dislocations with increasing gran size. E-twins seem to be confined to grains larger than $60-$ $80 \mu \mathrm{m}$, i. e. to the coarsest matrix grains in B 96 and Pt 205 , and to the calcite corphyroclasts in all specimens. E-twin glide is a comparatively "coarse" slip mechanism, and twin propagation may be suppressed for finer grain sizes because of the strain incompatibilities caused at the numerous grain interfaces.

Finally, there are clear differences in the grain aspect ratios of the matrix. This matter will be discussed later.

Another point of interest is the variation of size spectra of recrystallized grains with mean grain diameter, as shown in Fig. 4. Grain sizes (d) of a random sample of fifty grains per specimen have been determined by measuring the long and short axes and taking their arithmetic mean. Classed in $5 \mu \mathrm{m}$ intervals, they yield a characteristic spectrum, which varies with the average grain size (d). Whereas the four fine-grained specimens display normal, or near normal distributions, a breakdown of the spectrum into several maxima is observed for Pt 205 and B 96. This suggests that selective grain growth and grain consumption by migrating boundaries could modify originally normal size distributions in the coarser samples.

\section{Fabrics}

Crystallographic orientations have been measured for calcite c-axes (and dolomite c-axes in B 43) in all specimens using an optical microscope with universal stage (Fig. 5). The difficulties normally encountered in finding the accurate location of the c-axis (TuRNER and WEIss, 1963) are avoided by the extreme thinning of the sections. The measurement procedure is identical to the one commonly used for quartz. The reproducibility of measurements was checked for grain sizes of $5-200 \mu \mathrm{m}$, and was found to vary from $6^{\circ}$ to $1^{\circ}$ in azimuth, and from $11^{\circ}$ to $2^{\circ}$ in inclination. Population outlines of the pole figures stabilize after the measurement ob about 100 c-axes.

Pole figures for $\mathrm{r}$ - and a-planes were measured on a Seiffert-Scintag X-ray texture goniometer in combined reflection and transmission modes (Siddans, 1976), using $\mathrm{Co} \mathrm{K} \alpha$ radiation. Counting times were $10 \mathrm{sec}$. for each $5^{\circ}$ step in tilt and azimuth, and 40 sec. for two background positions per tilt increment. The defo- 


\section{J. H. Behrmann}
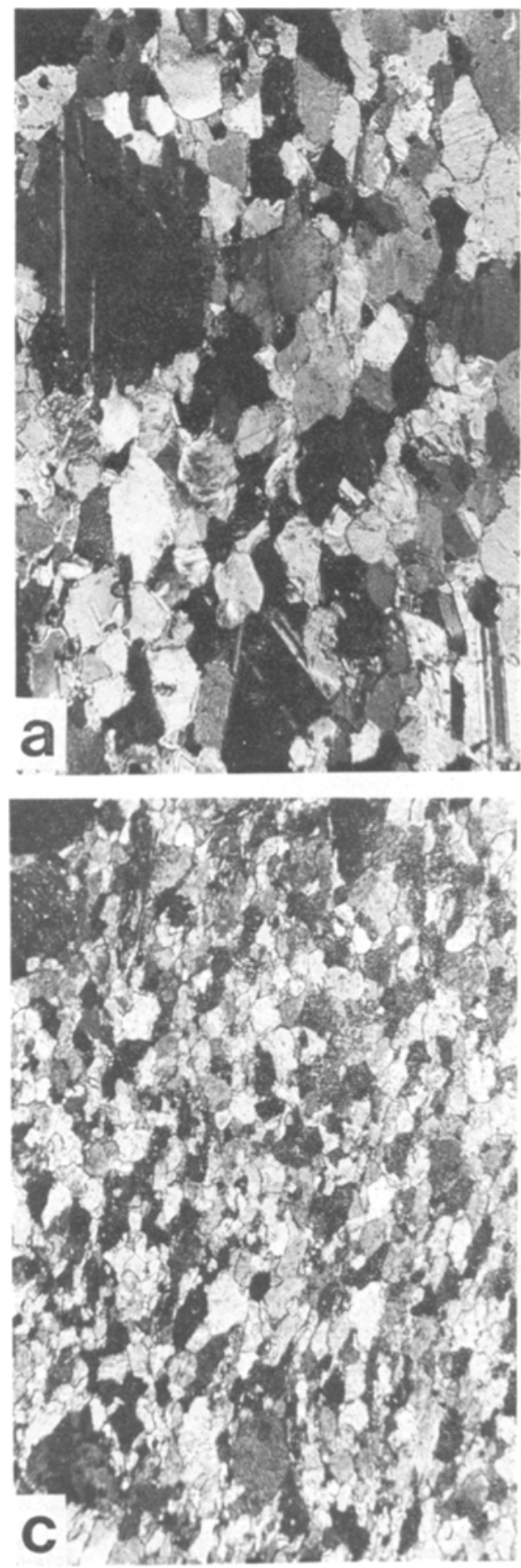
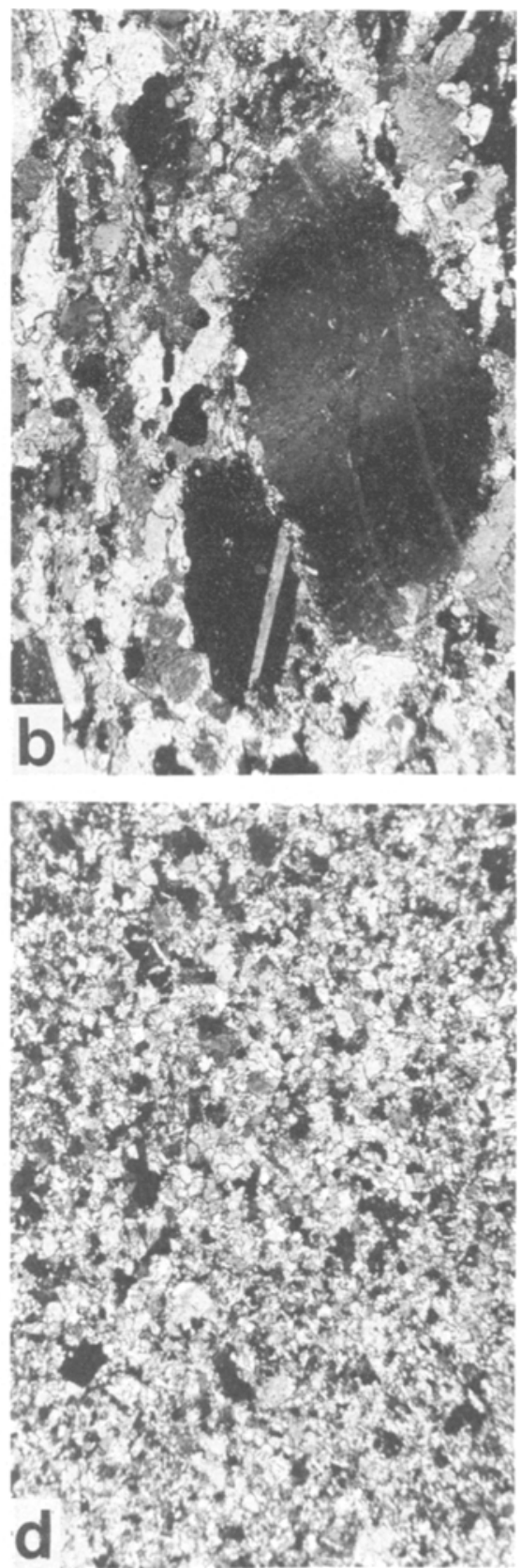

Fig. 3. Selected aspects of recrystallized calcite microstructures; a: B96, b: Pt 205; c: B12, d: B43. The mesoscopic foliation runs N-S. The long side of the photomicrographs is $1 \mathrm{~mm}$. For further explanation see text. 
Microstructure and fabric transitions in calcite tectonites

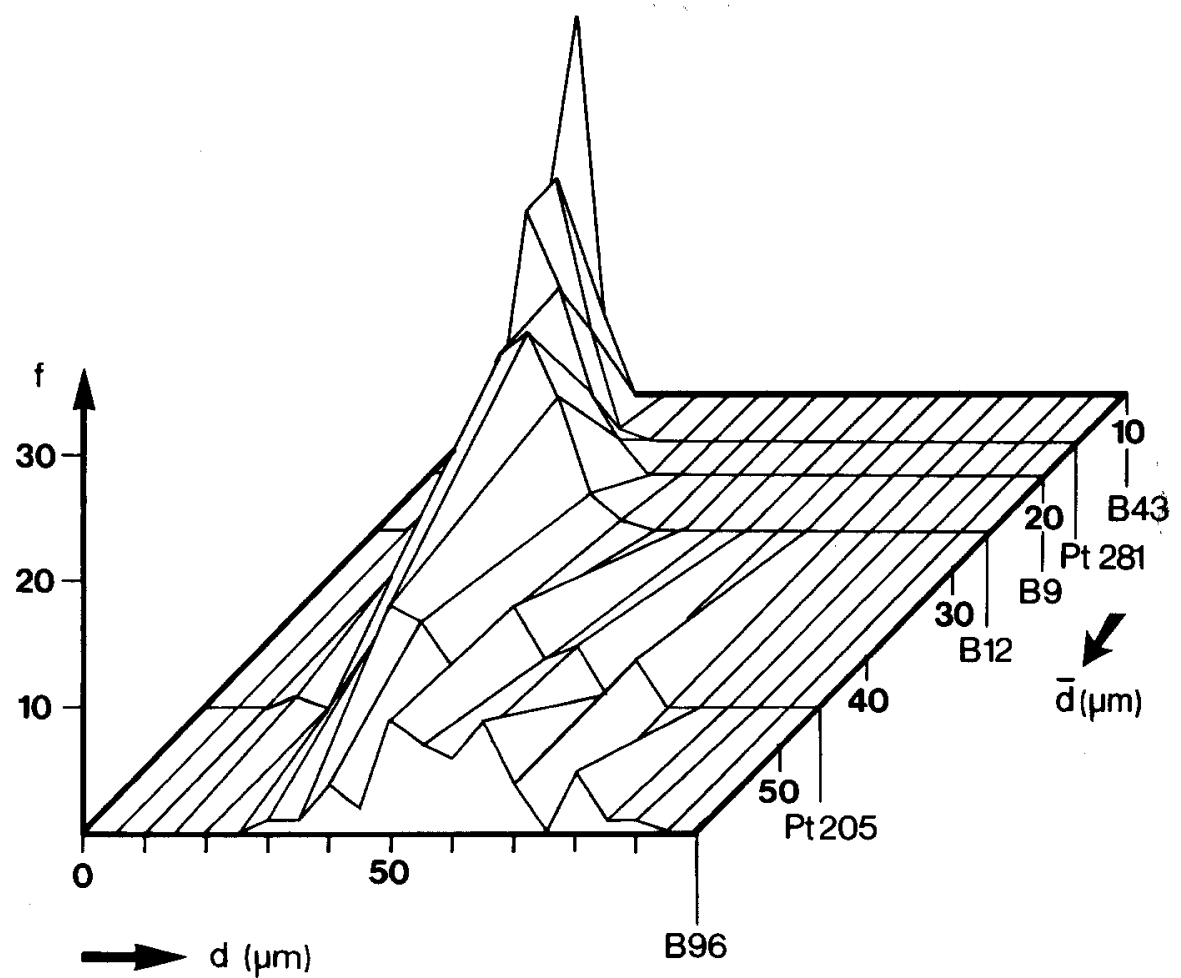

Fig. 4. Variation of size spectra of recrystallized grains (d) with mean grain diameter (d). $f$ ist the frequency of grain sizes in a $5 \mu \mathrm{m}$ interval of $d$.

cussing correction for the reflection mode is the same as applied in ScHmid et:al. (1981). The results are shown in Fig. 5.

B 96 has a well developed single maximum distribution of c-axes inclined at $20^{\circ}$ to the foliation normal. The peak population per $1 \%$ area (square dot) is $6.7 \mathrm{x}$ uniform distribution. The pole figures for $r$ and a show, that the fabric has approximately rotational symmetry around c. The c-axis fabric in $\mathrm{Pt} 205$ is similar (peak = $6.7 \mathrm{x}$ uniform) but has a less expressive outline. The single maximum is tilted away from the foliation normal by $10^{\circ}$ in the same direction. B 12 has a less distinct (peak $=5.8 \mathrm{x}$ uniform) preferred orientation of c-axes on a small circle of $40^{\circ}$ around Y. The X-ray pole figures give no distinct pattern for $\mathbf{r}$, but a weak maximum for a around $X$. The fabric of $B g$ is even weaker, with a peak population of $5.0 \mathrm{x}$ uniform for the c-axis. There is a near pole-free area around the lineation direction (X). Pt 281 has a near-random distribution of c-axes (peak $=4.0 \mathrm{x}$ uniform), with isolated, scattered maxima. The same is true for $B 43$, where the c-axes of recrystallized dolomite and calcite have an approximately random distribution (peak $=3.3 \mathrm{x}$ uniform). The pole figures for calcite $\mathrm{r}$ and $\mathrm{a}$, and for dolomite $r$ and a show no geometrical compatibility with the c-axis stereogram. This may be a volumetric effect due to the fact that c-axis measurements were taken on 
J. H. BehrmanN

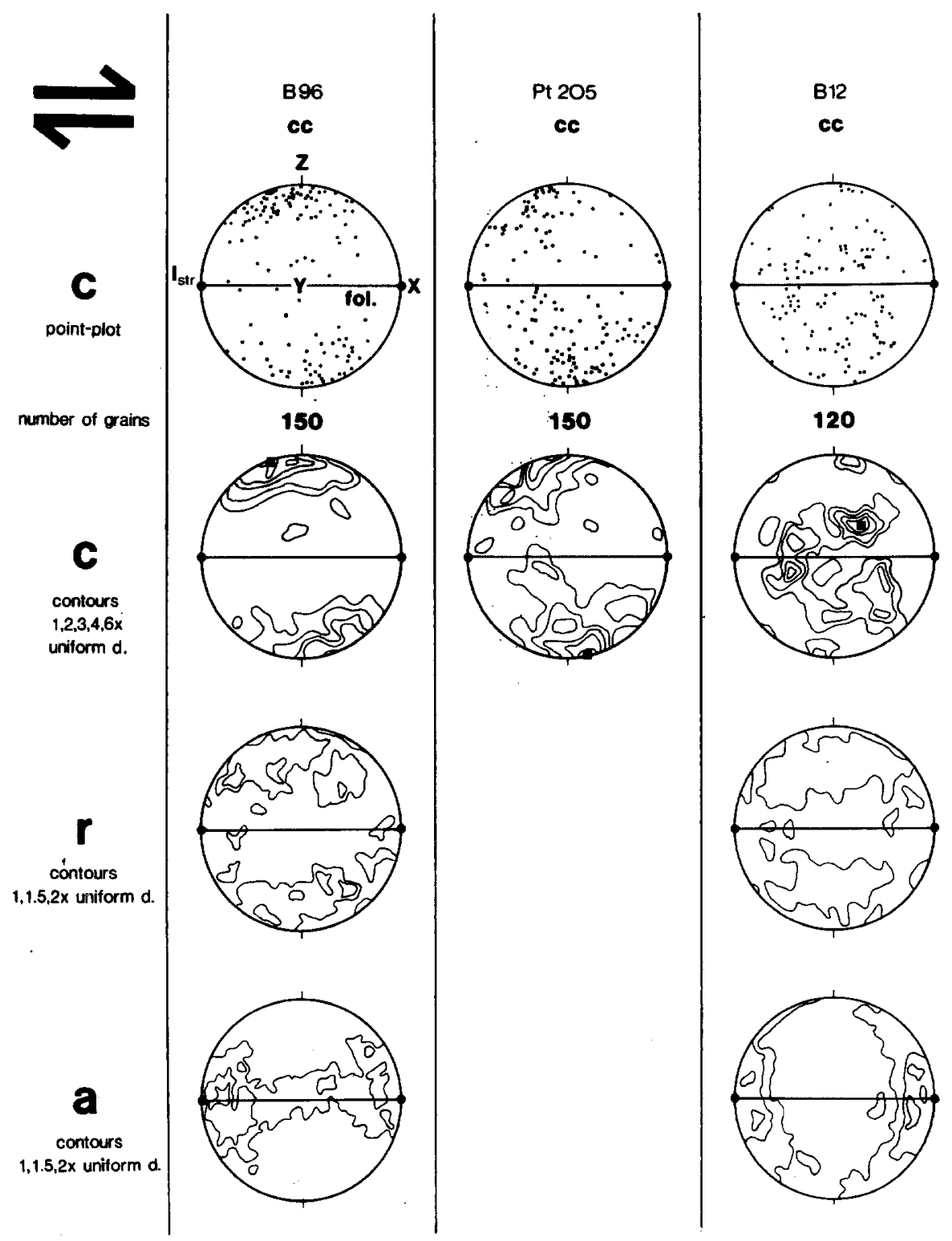


Microstructure and fabric transitions in calcite tectonites

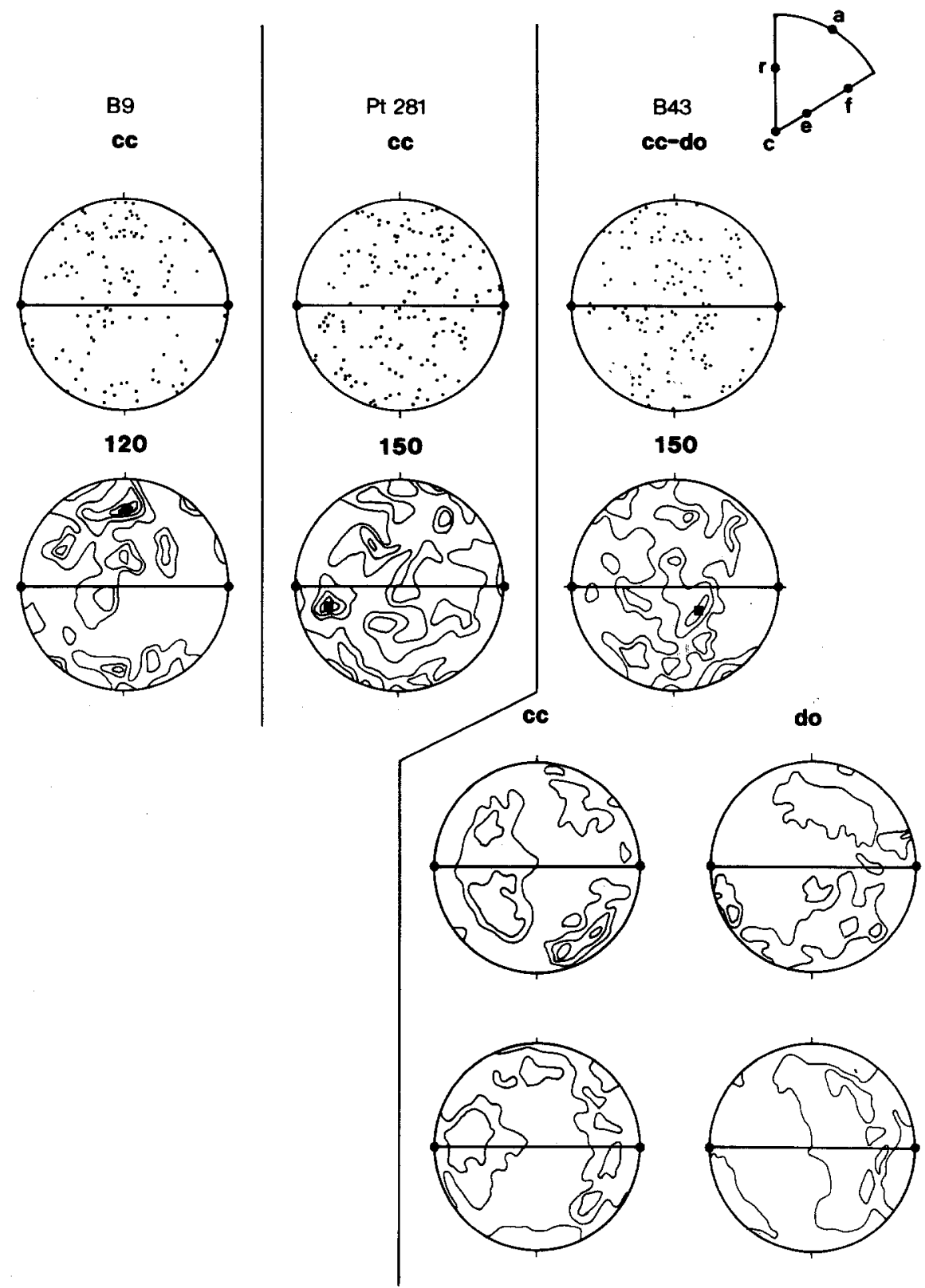

Fig. 5. Pole figures of the $c, r$, and a directions for calcite (cc), dolomite (do), and calcite + dolomite ( $\mathrm{cc}-\mathrm{do}$ ) of the specimens studied. (Fol.) indicates the trace of mesoscopic foliation and $1_{\mathrm{str}}$ is the stretching direction. $\mathrm{X}, \mathrm{X}, \mathrm{Z}$ refer to the kinematic axes of Fig. 2. All pole figures are equal area, lower hemisphere. The regional sense of shear is indicated by the pair of arrows. For explanation, see text. 


\section{J. H. BehrmanN}

matrix grains only, whereas the texture goniometer may have picked up a preferred orientation within the numerous calcite and dolomite porphyroclasts (Schmid et al., 1981).

Generally, the development of lattice preferred orientations in plastically deforming crystal aggregates can be attributed to dislocation glide on crystallographic planes, and their rotation during straining. Hence, this mechanism must have contributed significantly to deformation in B 96, Pt 205, and to a lesser extent in B 12 and B 9. B 96 and Pt 205 have c-axis fabric topologies which are quite commonly encountered in coarse grained, naturally deformed marbles (e. g. SANDER, 1970; Wenk et al., 1968). Rutter and Rusbridge (1977) produced similar preferred orientations in non-coaxial deformation of Carrara marble. The relation between fabric symmetry and sense of shear in our samples is the same as in RutTer and Rusbridge's experiments. For microstructural reasons, e-twinning is argued not to be important in the development of these fabrics, but they can be easily related to dominant slip on $r_{1}$ in an $r_{2}: f_{1}$ direction (WENK et al., 1973). The possibility of translation in the negative (TurNer et al., 1954) and positive senses (SpIERs, 1981) has been ascertained for $r$-slip. The preferred orientation pattern in B 12 cannot be easily related to certain slip systems. The position of the c-axis maxima may suggest an easy glide orientation for one of the f-planes, but the supporting evidence from the r-pole figure is really too scanty to make any predictions. The weak preferred orientation of a around the stretching axis (X) supports the idea that slip is in an $\mathrm{r}: \mathrm{f}$ direction.

\section{Relation between Microstructure and Fabric Parameters; Inferences for Deformational Behavior}

The intensity, or degree of preferred orientation of a fabric can most simply be defined by the height of the peak population in a c-axis fabric diagram, and will be expressed as multiples of the uniform distribution (4). The fabric intensity is interpreted as proportional to the activity of dislocation glide as a deformational mechanism. Variation in strains should not affect this parameter, provided that total strain is large. Rapid development of saturation intensities was observed in progressive deformation of polycrystalline calcite (RUTTER and RUSBRIDGE, 1977).

The aspect ratio of dynamically recrystallized grains, here expressed as the ratio of the longest and shortest axes (X/Z) may indicate the action of several deformational mechanisms. Marked shape change of crystals is conceivable in both diffusional and dislocation creep, but not in superplastic behaviour (AsHBY and VERALL, 1973), which involves sliding on grain boundaries of essentially rigid crystallites as major strain producing mechanism.

Finally, the bulk grain size (d), in our example represented by the recrystallized matrix, has an important bearing on rheology, especially in low temperature deformation. If climb is limited, the mobility of dislocations is affected in the form of the Hall-Petch law (see e. g. Honercombe, 1968), and hence the feasibility of dislocation glide. The Hall-Petch law has been shown to be valid for polycrystalline calcite for temperatures up to $300^{\circ} \mathrm{C}$ (OLsson, 1974). On the other hand the increase in grain surface per unit volume with decreasing grain size catalyzes grain boundary diffusion in the form of Coble creep (CoBLe, 1963) or pressure solution (RuTTER, 1976). 


\section{Microstructure and fabric transitions in calcite tectonites}

The inter-relationships of these three parameters $(A, \mathrm{X} / \mathrm{Y}, \mathrm{d})$ are shown in Figs. $6 a-6$ c. Fig. 6 a depicts the development of crystallographic preferred orientation (A) with increasing recrystallized grain size (d). Between 10 and $25 \mu \mathrm{m}$, there is a rapid fabric build-up, which stabilizes for larger grain sizes at about $7 \mathrm{x}$ uniform distribution for the peak population. Essentially this observation is not a new one: SANDER (1970, p. $460 \mathrm{f})$ noted, that "large, mechanically deformed grains produce sharply defined patterns", whereas recrystallized small ones yield "diffuse" ones. As a conclusion, the importance of dislocation glide seems to increase with grain size, and attains a stable level at grain sizes larger than $45 \mu \mathrm{m}$. Fig. $6 \mathrm{c}$ correlates aspect ratios and recrystallized grain size $(\mathrm{X} / \mathrm{Z}$ and $\mathrm{d})$. Rapid development of a grain shape fabric is observed between 10 and $15 \mu \mathrm{m}$ grain diameter. Further, but slower increase leads to a saturation value of about 1.7 for larger grain sizes.

If the developments of preferred orientation and grain shape fabric were a function of the same process, a correlation of the two parameters should give a straight line. Fig. $6 \mathrm{~b}$ demonstrates, that the build-up of crystallographic preferred

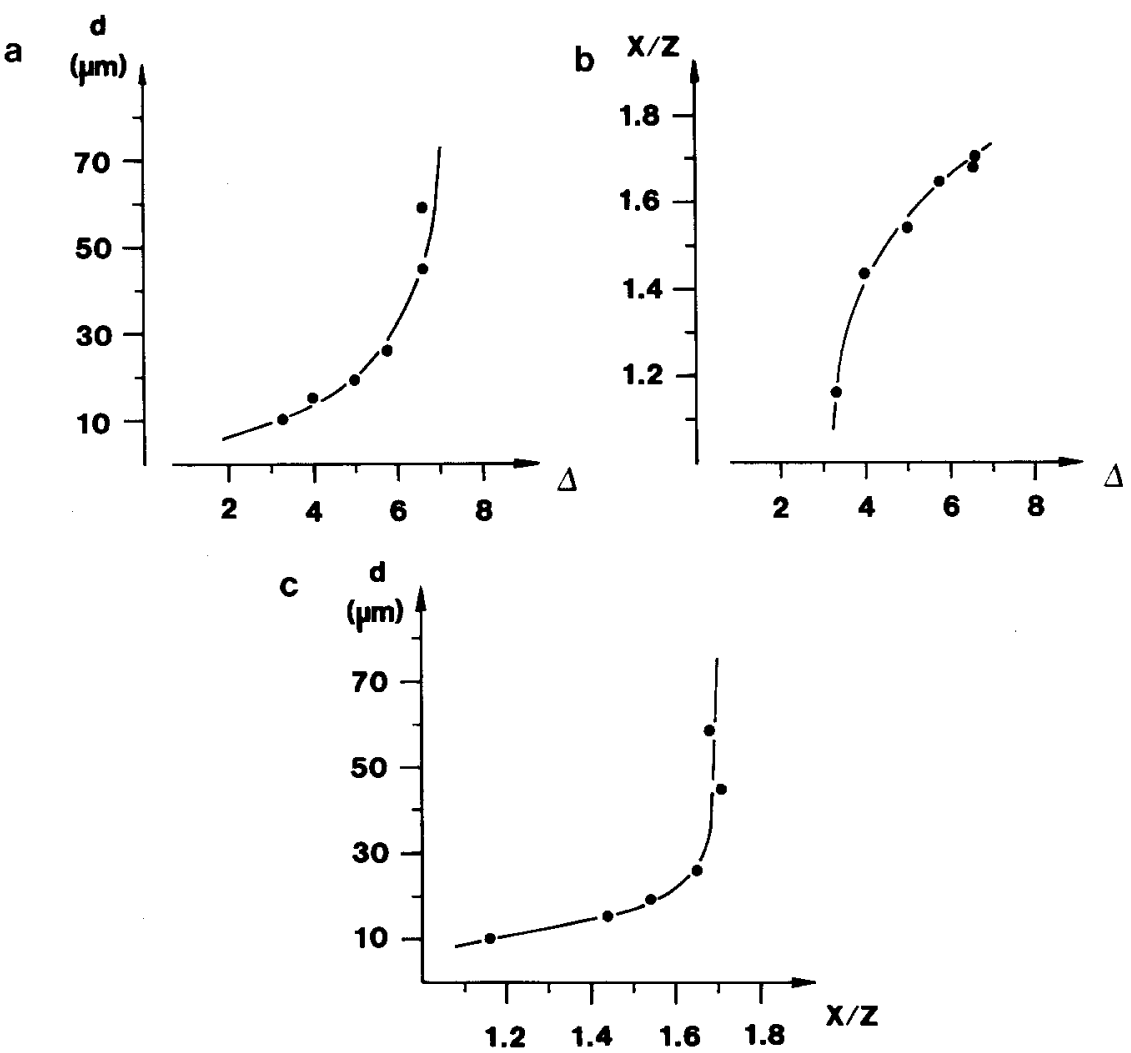

Fig. 6. Diagrams relating intensity of crystallographic fabric $(\Delta)$, intensity of grain shape fabric $(\mathrm{X} / \mathrm{Z})$, and average recrystallized grain size (d) for the specimens analyzed. For discussion see text. 


\section{J. H. BEHRMANN}

orientation lags behind the formation of the grain shape fabric. If we propose that diffusional creep can change the shape of crystals, we have to conclude that it makes an essential contribution to deformation at grain sizes between 10 and $60 \mu \mathrm{m}$. Furthermore, we can conclude that specimen B 43 deformed in a superplastic manner. This may be realistic, because it has a grain size commonly considered to allow superplastic flow (Nicolas and Porrier, 1976). The intrinsic mixture of calcite and dolomite in the matrix is akin to an eutectoid alloy, helping to stabilize the small grain size.

A deformaton regime map for calcite at $300^{\circ} \mathrm{C}$, computed from the flow laws of Yule marble (HEARD and Raleigh, 1972), and superplastic Solnhofen limestone (SCHMid et al., 1977) seems to illustrate our case quite well (Fig. 7). For Yule marble, the laws for " $T$ " orientation (unfavourable for twinning) were used according to the equations formulated by ScHmid et al. (1979). There is a transition from an exponential flow law (low temperature plasticity, LTP) to power law creep (PLC) with a very high stress exponent (7.7) at a differential stress of 1.4 kbar. To extrapolate the flow law of Solnhofen limestone to different grain sizes, a strain rate sensitivity of grain size (d)

$$
\frac{\dot{\varepsilon}}{\dot{\varepsilon}_{0}}=\mathrm{d}^{-3}
$$

was assumed (EDINGTon et al., 1976). $\varepsilon_{0}$ is the strain rate for $\mathrm{d}=1 \mu \mathrm{m}$. We can see, that for geologically relevant strain rates $\left(10^{-13}\right.$ to $\left.10^{-14} \mathrm{sec}^{-1}\right)$, a switch from power law creep to superplasticity (grain size sensitive creep, GSC) is predicted

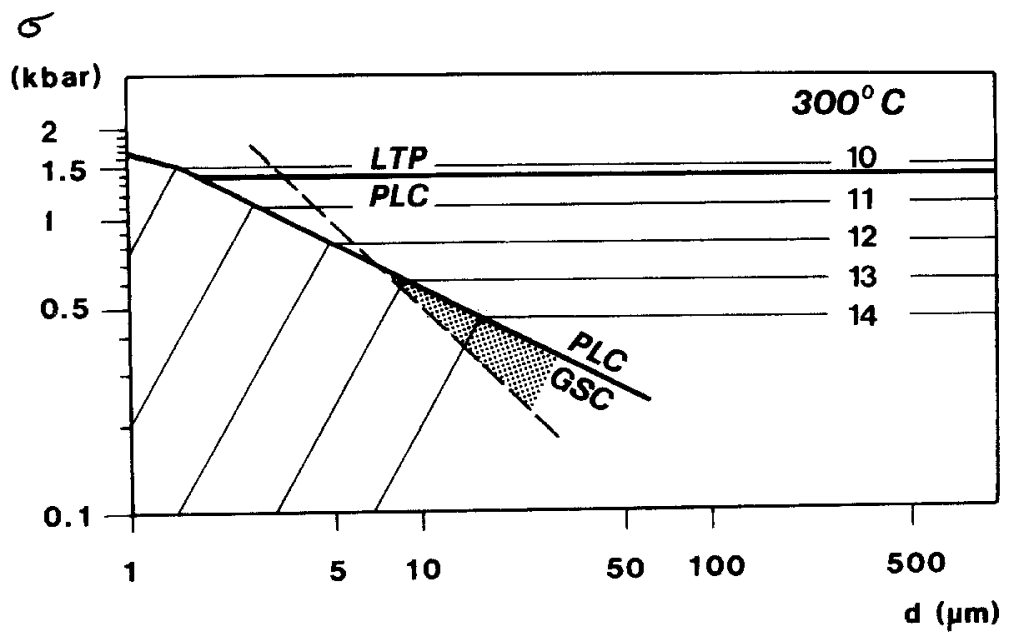

Fig. 7. Deformation regime map for polycrystalline calcite in grain size - stress space at $300^{\circ} \mathrm{C}$, divided into fields of low temperature plasticity (LTP), power law creep (PLC), and superplastic grain size sensitive creep (GSC). The dashed line marks the equilibrium recrystallized grain size produced in steady state power law creep; the stippled area outlines the conditions under which superplasticity is conceivable. Strain rate contours are $10^{-\mathrm{x}} \mathrm{sec}^{-1}$. 
at grain sizes ranging from 9 to $16 \mu \mathrm{m}$. The grain sizes which can be produced by dynamic recrystallization in power law creep of coarse grained marble depending on differential stress (Schmid et al., 1979) are shown by the broken line. Below $\sigma=0.7 \mathrm{kbar}$, a recrystallized aggregate of this grain size is expected to deform in a superplastic manner (stippled area). This is compatible with the inferences made from microstructure and fabric of B 43 .

The rapid development of a grain shape fabric above $10 \mu \mathrm{m}$ grain diameter in our specimens suggests, that the transition from superplastic flow to power law creep is a relatively sharp one. On the other hand, the field of power law creep in grain size/stress space (Fig. 7) delineates a flow regime, rather than a particular deformational mechanism. It may host areas of dominant diffusional creep towards small, and dominant dislocation creep towards large grain sizes. It should be noted however, that the possibilities of changes in flow laws with average grain size have not been explored experimentally. This means that the strain rate contours within the field of power law creep may not be perfectly grain size invariant. The data presented here suggest that the shift in deformation mechanisms is gradual, and may span a grain size range of about $30 \mu \mathrm{m}$.

\section{Acknowledgements}

I am particularly indebted to S. SCHMID and M. CASEx, of ETH Zürich, who enabled me to measure the X-ray textures of some of the specimens. J. Platr kindly provided samples Pt 205 and Pt 281. Field work was supported by a travel grant of The Queen's College, Oxford.

\section{References}

Ashby, M. F., \& Verall, R. A.: Diffusion accommodated flow and superplasticity. Acta Metall., 21, 149-163, 1973.

Behrmann, J. H. \& Platt, J. P.: Sense of nappe emplacement from quartz c-axis fabrics; an example from the Betic Cordilleras (Spain). - Earth and Planet. Sci. Lett., 59, 208-215, 1982.

Brgkle, M. J. \& Powelt, R.: Calcite-dolomite geothermometry from iron-bearing carbonates. - Contr. Mineral. Petrol., 59, 281-292, 1977.

CoBLE, R. L.: A model for boundary diffusion controlled creep in polycrystalline materials. - J. Appl. Phys., 34, 1679-1682, 1963.

Edington, J. W., Melton, K. N. \& Cutler, C. P.: Superplasticity. - Progr. Mater. Sci., 21, 63-170, 1976.

Egeler, C. G. \& Simon, O. J.: Sur la tectonique de la Zone Bétique (Cordillères Bétiques, Espagne). -- Verh. Kon. Ned, Akad. Wetensch., 25, 90 pp., 1969.

Escher, A. \& Watterson, J.: Stretching fabrics, folds and crustal shortening. - Tectonophysics, 22, 223-231, 1974.

Handin, J. W. \& Griggs, D. T.: Deformation of Yule marble. Part II: predicted fabric changes. - Geol. Soc. Amer. Bull., 62, 863-886, 1951.

Heard, H. C. \& Raleigh, C. B.: Steady state flow in marble at $500^{\circ}$ to $800^{\circ}$ C. - Geol. Soc. Amer. Bull ., 83, 935-956, 1972.

Honexcombe, R. W. K.: The plastic deformation of metals. -- Arnold, London, 477 pp., 1968.

KERN, H.: Dreiaxiale Verformungen an Solnhofener Kalkstein im Temperaturbereich von $20^{\circ}-650^{\circ} \mathrm{C}$. Röntgenographische Gefügeuntersuchungen mit dem Texturgoniometer. - Contr. Mineral. Petrol., 31, 39--66, 1971. 


\section{J. H. BeHRMANN}

Lister, G. S.: Texture transitions in plastically deformed calcite rocks. In: G. Gottstein \& K. Lücke (ed.). Textures of materials, Springer Verlag, 199-210, 1978.

Means, W. D., Honbs, B. E., Lister, G. S. \& Williams, P. F.: Vorticity and noncoaxiality in progressive deformation. - J. Struct. Geol., 2, 371-378, 1980.

Nicolas, A. \& Poirier, J. P.: Crystalline plasticity and solid state flow in metamorphic rocks. - Wiley, London, 444 pp., 1976.

OLsson, W. A.: Grain size dependence of yield stress in marble. -- J. Geophys. Res., 79, 4859-4862, 1974.

Platt, J. P.: The emplacement of fold nappe, Betic orogen, Southern Spain. — Geology, 10, 97-102, 1982.

Rutrer, E. H.: The kinetics of rock deformation by pressure solution. - Phil. Trans. Roy. Soc. Lond. A, 283, 203-219, 1976.

Rutter, E. H. \& Rusbridge, M.: The effect of non-coaxial strain paths on crystallographic preferred orientation development in the experimental deformation of a marble. - Tectonophysics, 39, 73-86, 1977.

SANDER, B.: An introduction to the study of fabrics of geological bodies. - Pergamon, Oxford, 641 pp., 1970.

Schmid, S. M., Boland, J. N. \& Paterson, M. S.: Superplastic flow in finegrained limestone. - Tectonophysics, 43, 257-291, 1977.

Schmid, S. M., Paterson, M. S. \& Boland, J. N.: High temperature flow and dynamic recrystallization in Carrara marble. - Tectonophysics, 65, 245-280, 1979.

Schmid, S. M., Caser, M. \& STARker, J.: The microfabric of calcite tectonites from the Helvetic Nappes (Swiss Alps). — In: McClay, K. R. \& Price, N. J. (eds.), Thrust and nappe tectonics: Geol. Soc. Lond. Spec. Publ. 9, 151-158, 1981.

Siddans, A. W. B.: Deformed rocks and their textures. - Phil. Trans. Roy. Soc. London A, 283, 43-54, 1976.

Spiers, C. J.: Evidence for slip on $r$ and $f$ in the positive sense in deformed calcite single crystals. - In R. G. Park (ed.), Report on the Tectonic Studies Group A. G. M., Keele. J. Struct. Geol., 3, 185-195, 1981.

Torres-Roldan, R. L.: The tectonic subdivision of the Betic zone (Betic Cordilleras, southern Spain): its significance and one possible geotectonic scenario for the westernmost alpine belt. - Am. J. Sci., 279, 19-52, 1979.

Turner, F. J., Griggs, D. T. \& Heard, H. C.: Experimental deformation of calcite crystals. - Geol. Soc. Amer. Bull., 65, 883-934, 1954.

TURNER, F. J. \& WEIss, L. E.: Structural analysis of metamorphic tectonites. - McGrawHill, New York 545 pp., 1963.

VERNON, R. H.: Optical microstructure of partly recrystallized calcite in some naturally deformed marbles. - Tectonophysics, 78, 601-612, 1981.

Wenk, H. R., TrommsdorfF, V. \& Baxer, D. W.: Inverse pole figures of two carbonate fabrics. - Schweiz. Mineral. Petrogr. Mitt., 48, 467-470, 1968.

Wenk, H. R., Venkttasubramanyan, C. S. \& Baker, D. W.: Preferred orientation in experimentally deformed limestone. - Contr. Mineral. Petrol., 38, 81-114, 1973.

WrLtiams, P. F.: Relationships between axial-plane foliations and strain. - Tectonophysics, 30, 181-196, 1976. 